\title{
PENGARUH VARIASI JUMLAH METANOL DALAM REAKSI PEMBUATAN BIODIESEL DARI FRAKSI STEARIN MINYAK SAWIT
}

\author{
Ineke Febrina A. ${ }^{1)}$, Aldri Yongki Hijriah ${ }^{2)}$ \\ ${ }^{1,2)}$ Program Studi Teknik Analisis Laboratorium Migas Politeknik Akamigas Palembang, 30257, Indonesia
}

\begin{abstract}
Abstrak: Transesterifikasi adalah tahap konversi dari stearin menjadi metil ester, melalui reaksi dengan metanol dan menghasilkan produk samping gliserol dengan kondisi operasi temperatur $65-70{ }^{\circ} \mathrm{C}$. Biodiesel yang terbentuk dari variasi penambahan metanol, terdapat kenaikan dari standar mutu biodiesel seperti densitas $\left(854,1-857,2 \mathrm{~kg} / \mathrm{m}^{3}\right)$, viskositas $(4,3-5,1 \mathrm{cSt})$, air dan sedimen $(0,00-0,15 \% \mathrm{vol})$, temperatur distilasi $\left(351,8-422,5{ }^{\circ} \mathrm{C}\right)$, angka iodium (37,17 - 61,93 \% massa) dan residu karbon (0,2 - 2,2\% massa). Perolehan biodiesel yang memenuhi parameter uji adalah dengan menggunakan variasi rasio molar metanol/stearin 5 yang sesuai dengan Standar Nasional Indonesia (SNI 04-7182 : 2006). Sertifikat produk diperlukan untuk memberikan jaminan mutu kepada pelanggan. Sertifikat produk menyatakan kesesuain suatu produk yang dihasilkan secara berulang oleh suatu unit produksi terhadap standar produk atau regulasi teknis tertentu.
\end{abstract}

Kata Kunci : Transesterifikasi, Variasi Metanol, Sertifikat Produk.

\section{PENDAHULUAN}

\subsection{Latar Belakang}

Energi yang dibutuhkan masyarakat dan industri mengalami peningkatan setiap tahunnya. Mengingat cadangan minyak bumi Indonesia yang semakin menipis, impor minyak bumi yang semakin tinggi dan kenaikan harga minyak bumi dunia yang dapat dipastikan akan diikuti oleh kenaikan harga BBM.. Akibat dari permasalahan tersebut maka diperlukan pengembangan energi alternatif terbarukan. Salah satu sumber energi alternatif yang berpotensi untuk dikembangkan di Indonesia adalah biodiesel.

Biodiesel merupakan bahan bakar yang terdiri dari campuran mono-alkil ester dari rantai panjang asam lemak, yang dipakai sebagai alternatif bagi bahan bakar dari mesin diesel dan terbuat dari sumber terbaharui seperti minyak nabati dan hewani.

Salah satu bahan baku yang dapat digunakan untuk pembuatan biodiesel yaitu fraksi stearin dari minyak sawit. Fraksi stearin secara alami berada pada posisi yang menguntungkan sehubungan dengan pola permintaan konsumen besar untuk lemak padat.

Terdapat beberapa hambatan yang dialami mesin diesel konvensional jika memakai bahan bakar minyak nabati secara langsung. Hal ini disebabkan oleh derajat kekentalan (viskositas) minyak nabati sepuluh sampai dua puluh kali lebih besar dari viskositas solar (petrodiesel). Masalahmasalah ini dapat diselesaikan dengan menyesuaikan mesin pada spesifikasi bahan bakarnya maupun mendekatkan bahan bakarnya pada spesifikasi mesinnya.

Strategi yang dilakukan untuk memodifikasi minyak nabati dengan berbagai teknologi salah satunya dengan membuat variasi dalam pembuatan biodiesel dengan penambahan metanol. Metanol merupakan alkohol yang paling sederhana yang dapat ditemukan dan memiliki hanya satu ikatan senyawa karbon sehingga mudah untuk melepaskan karbon agar dapat membentuk ikatan rangkap menjadi metil ester untuk menghasilkan bahan bakar dengan sifat-sifat yang mendekati bahan bakar solar (konvensional). Selain itu metanol memiliki harga yang lebih ekonomis daripada alkohol yang lain ditambah lagi dengan penyimpanan dan penanganan yang mudah.

Konsep penggunaan minyak tumbuhtumbuhan sebagai bahan pembuatan bahan bakar sudah dimulai pada tahun 1895 oleh Dr. Rudolf Christian Karl Diesel (Jerman,18581913)

1. Pada saat itu, minyak untuk mesin diesel yang dibuat oleh Dr. Rudolf Christian Karl Diesel tersebut berasal dari minyak sayuran. Tetapi 
karena pada saat itu produksi minyak bumi (petroleum) sangat melimpah dan murah, maka minyak untuk mesin diesel tersebut digunakan minyak solar dari minyak bumi. Hal ini menjadi inspirasi terhadap penerus Karl Diesel yang mendesain motor diesel dengan spesifikasi minyak diesel. Pemerintah Indonesia telah melaksanakan pengembangan dan implementasi bahan bakar diesel, bukan hanya untuk menanggulangi krisis energi tetapi juga sebagai salah satu solusi kebangkitan ekonomi masyarakat.

\section{TEORI DASAR}

\subsection{Perkembangan Biodiesel}

Energi yang dibutuhkan masyarakat dan industri mengalami peningkatan setiap tahunnya. Hal ini berdampak besar bagi ketersediaan energi tersebut di masa depan. Oleh karena itu, penelitian mengenai energi alternatif yang terbarukan serta penerapannya berkembang pesat dalam beberapa tahun terakhir ini. Biodiesel adalah suatu energi alternatif yang telah dikembangkan secara luas untuk mengurangi ketergantungan kepada BBM. Sebagai bahan bakar, biodiesel mampu mengurangi emisi hidrokarbon tak terbakar, karbon monoksida, sulfat, hidrokarbon polisiklik aromatik, nitrat hidrokarbon polisiklik aromatik dan partikel padatan sehingga biodiesel merupakan bahan bakar yang disukai disebabkan oleh sifatnya yang ramah lingkungan.

Di beberapa negara, biodiesel telah diproduksi dan dikonsumsi dalam jumlah banyak. Pada tahun 2008 produksi biodiesel di Amerika Serikat mencapai 700 juta galon. Sebagian besar bahan baku yang digunakan dalam produksi biodiesel di negara-negara tersebut adalah minyak kedelai, minyak kanola, minyak kelapa sawit, dan minyak biji bunga matahari. Namun, penggunaan bahan baku tersebut menjadi kendala baru bagi pemenuhan kebutuhan pangan. Oleh karena itu, pencarian bahan baku baru untuk biodiesel sangat diperlukan.

\subsection{Fraksi Stearin}

Minyak kelapa sawit pada dasarnya terdiri dari dua bagian yaitu stearin (fraksi padatan) dan olein (fraksi cairan). Fraksi stearin merupakan produk samping yang diperoleh dari minyak sawit bersamaan dengan fraksi olein. Sebagai produk samping, stearin cukup berperan dalam perdagangan internasional. Fraksi stearin secara alami berada pada posisi yang menguntungkan sehubungan dengan pola permintaan konsumen yang besar untuk lemak padat. I

Crude palm stearin merupakan stearin yang dihasilkan dari proses fraksinasi CPO dengan karakter fisik berwarna kuning hingga jingga kemerahan (SNI 01-0019-1987). Berdasarkan SNI 01-0021-1998, stearin merupakan produk yang diperoleh dari hasil fraksinasi RBD PO dan telah mengalami proses pemurnian. Standar RBD stearin harus dipenuhi jika stearin akan dipergunakan untuk membuat suatu produk pangan.

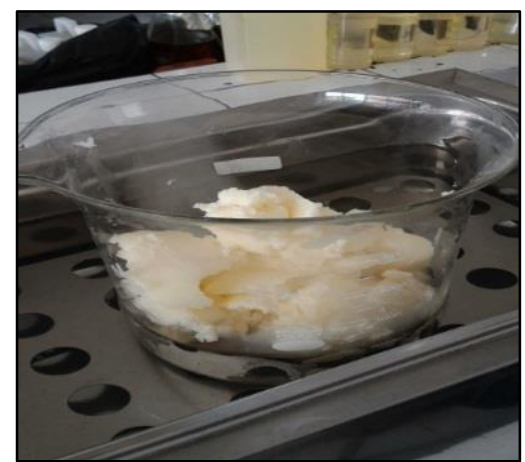

\section{Gambar 2.1 Bahan Baku Fraksi Stearin}

\subsection{Metanol}

Metanol juga dikenal sebagai metil alkohol, wood alcohol atau spiritus, adalah senyawa kimia dengan rumus kimia $\mathrm{CH}_{3} \mathrm{OH}$. Metanol digunakan sebagai bahan pendingin anti beku, pelarut, bahan bakar dan sebagai bahan aditif bagi etanol industri. Metanol diproduksi secara alami oleh metabolisme anaerobik oleh bakteri. Hasil proses tersebut adalah uap metanol (dalam jumlah kecil) di udara. Reaksi kimia metanol yang terbakar di udara dan membentuk karbon dioksida dan air sebagai berikut:

$$
2 \mathrm{CH}_{3} \mathrm{OH}+3 \mathrm{O}_{2} \rightarrow 2 \mathrm{CO}_{2}+4 \mathrm{H}_{2} \mathrm{O}
$$


Karena sifatnya yang beracun, metanol sering digunakan sebagai bahan aditif bagi pembuatan alkohol untuk penggunaan industri. Metanol kadang juga disebut sebagai wood alcohol karena dahulu metanol merupakan produk samping dari distilasi kayu. Saat ini metanol dihasilkan melului proses multi tahap. Secara singkat, gas alam dan uap air dibakar dalam tungku untuk membentuk gas hidrogen dan karbon monoksida, kemudian, gas hidrogen dan karbon monoksida ini bereaksi dalam tekanan tinggi dengan bantuan katalis untuk menghasilkan metanol. Tahap pembentukannya adalah endotermik dan tahap sintesisnya adalah eksotermik

\subsection{NaOH (Natrium hidroksida)}

Natrium hidroksida $(\mathrm{NaOH})$ juga dikenal sebagai soda kaustik atau sodium hidroksida, adalah sejenis basa logam kaustik. Natrium hidroksida terbentuk dari oksida basa natrium oksida dilarutkan dalam air.

Natrium hidroksida murni berbentuk putih padat dan tersedia dalam bentuk pelet, serpihan, butiran ataupun larutan jenuh $50 \%$. Natrium hidroksida bersifat lembab cair dan secara spontan menyerap karbon dioksida dari udara bebas.

\subsection{Transesterifikasi}

Transesterifikasi (biasa disebut dengan alkoholisis) adalah tahap konversi dari trigliserida (minyak nabati) menjadi alkil ester, melalui reaksi dengan alkohol dan menghasilkan produk samping yaitu gliserol. Reaksi transesterifikasi trigliserida menjadi metil ester adalah :

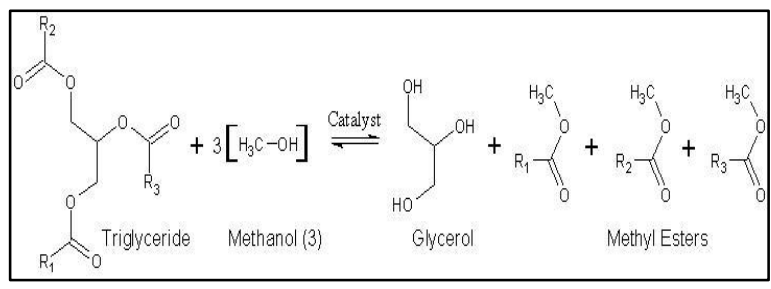

Gambar 2.2 Reaksi Pembuatan Biodiesel

Transesterifikasi juga menggunakan katalis dalam reaksinya. Tanpa adanya katalis, konversi yang dihasilkan maksimum, namun reaksi berjalan dengan lambat.

\section{METODOLOGI PENELITIAN 3.1 Metodologi Observasi}

Dengan cara melakukan pengamatan secara sistematis mengenai hal-hal yang terjadi di laboratorium, serta mengumpulkan datadata dan mengurutkan peristiwa-peristiwa yang terjadi. Dimana data yang diperoleh dari penelitian secara langsung tentang metode analisa sifat Fisika dan Kimia dari biodesel.

\subsection{Prosedur Pengujian}

Langka-langkah pengujian dilakukan sebagai berikut:

1. Stearin sebanyak $\pm 2.650 \mathrm{~g}$ dimasukkan kedalam beaker glass $5 \mathrm{~L}$, dicairkan di dalam waterbath $70{ }^{\circ} \mathrm{C}$, hingga jumlahnya sebanyak 3L.

2. Kemudian masukkan stearin yang sudah cair kedalam labu didih yang berfungsi sebagai reaktor dan dipanaskan sampel pada suhu $55{ }^{\circ} \mathrm{C}$ dan nyalakan stirrer (pengaduk yang terpasang didalan reaktor ke angka 4,5).

3. Timbang katalis $\mathrm{NaOH}$ sebanyak 30 gram dan metanol (sesuai dengan variasi $20 \%$, $30 \%$, 40\% dan 50\% dari bahan baku). Lalu campurkan ke dalam wadah gelas dan diaduk sampai homogen.

4. Masukkan campuran metanol + katalis ke labu didih yang terisi oleh stearin.

5. Kemudian naikkan suhu menjadi $65{ }^{\circ} \mathrm{C}$ dan diamkan selama 60 menit. (saat didiamkan, suhu tidak boleh naik dari $70^{\circ} \mathrm{C}$ dan tidak boleh turun dari $65^{\circ} \mathrm{C}$ ).

1

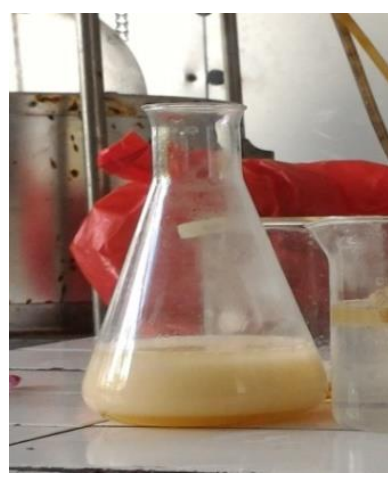

\section{Gambar 2.3 Contoh Sampel Fase Pemisahan}

6. Untuk mengetahui fasa pemisahannya ambil sampel dari bagian bawah labu dan 
masukkan kedalam gelas ukur dan tambah air panas.

7. Masukkan air panas $70{ }^{\circ} \mathrm{C}$ sebanyak 150 $\mathrm{ml}$ masukkan kedalam labu dan didiamkan selama 60 menit, setelah 60 menit akan terjadi pemisahan antara biodiesel (di atas) dan Gliserol (di bawah) kemudian keluarkan gliserol yang telah tercampur dengan air.

8. Kemudian lakukan washing (pencucian) biodiesel, dilakukan 2 tahap :

- Tahap pertama menggunakan air panas $70{ }^{\circ} \mathrm{C} \quad(50 \%$ dari biodiesel yang dihasilkan) dimasukkan kedalam reaktor dan didiamkan selama 60 menit, setelah 60 menit terjadi pemisahan antara air dan biodiesel, lalu air dikeluarkan.

- Tahap kedua menggunakan air panas $70{ }^{\circ} \mathrm{C} \quad(100 \%$ dari biodiesel yang dihasilkan) dimasukkan kedalam reaktor dan didiamkan selama 60 menit, setelah 60 menit terjadi pemisahan antara air dan biodiesel, lalu air dikeluarkan.

9. Drying biodiesel pada temperatur $110{ }^{\circ} \mathrm{C}$ (Selama 3 jam)

10. Tahapan terakhir lakukan penyaringan dengan menggunakan pompa vakum, kertas saring, corong buchner dengan dilakukan 2 kali penyaringan

11. Hasil Produk

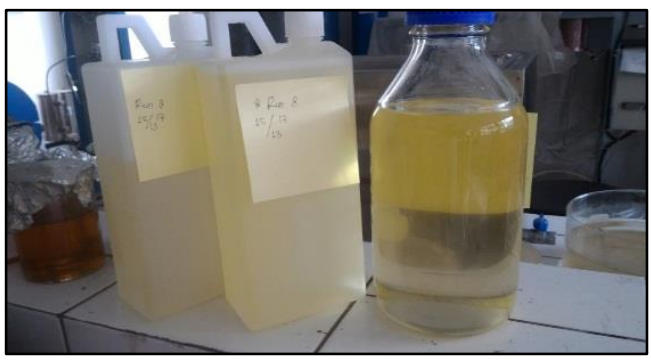

Gambar 2.4 Hasil Produk

\subsection{Parameter Uji Biodiesel} yaitu :

Parameter pengujian pada biodiesel ini,

1. Penentuan Densitas Cairan dengan Densitimeter Digital (Standard Test Method for Density and Relative Density of Liquid by Digital Density Meter) ASTM D-4052-11

2. Viskositas Kinematik ASTM D-445

3. Air dan Sedimen ASTM D-4007-11

4. Temperatur Destilasi 90\% ASTM D 1160

5. Residu Karbon ASTM D-4530

6. Angka Iodium AOCS Cd 1-25

\section{HASIL DAN PEMBAHASAN}

4.1 Data Hasil Analisa dan Pembahasan

4.1.2. Hasil Analisis Density ASTM D4052-11

Analisis density bertujuan untuk menentukan berat jenis dari suatu sample pada suhu tertentu dengan membandingkan berat contoh yang dianalisis dengan acuan standar yang telah ditentukan dan ditetapkan. Massa jenis adalah suatu angka yang menyatakan massa cairan minyak untuk setiap satuan volume yang diukur pada suhu tertentu. Dari hasil analisa density pada sampel biodiesel dengan variasi rasio molar metanol/stearin 5, 7, 9 dan 11 terjadi kenaikkan nilai densitas namun tidak terlalu signifikan. Densitas biodiesel terendah yang didapat adalah 854.1 $\mathrm{kg} / \mathrm{m}^{3}$ dengan variasi rasio molar metanol/stearin 5 sedangkan densitas tertinggi adalah $857,2 \mathrm{~kg} / \mathrm{m}^{3}$ dengan variasi rasio molar metanol/stearin 11 dapat dilihat dari grafik pada gambar 3.1.

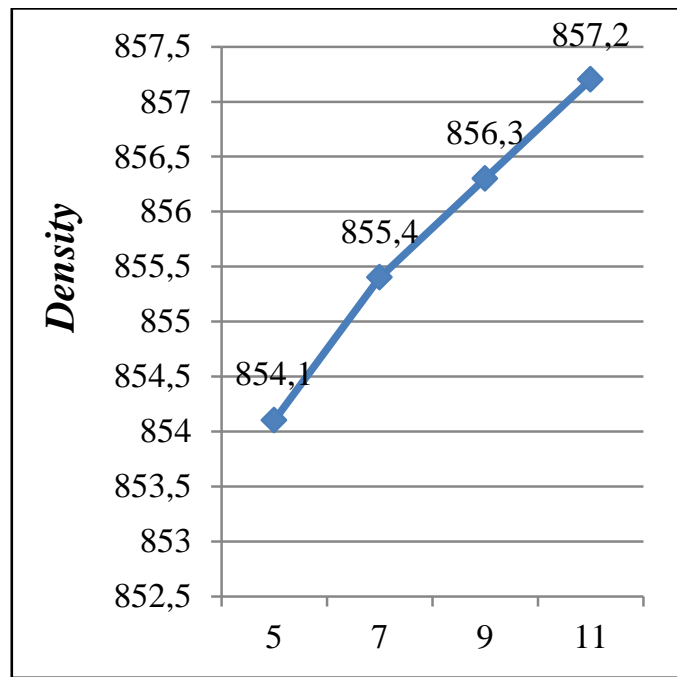

Gambar 3.1 Variasi Rasio Molar Metanol/Stearin Vs Density

Dari grafik variasi rasio molar metanol/stearin vs densitas diketahui nilai 
densitas semakin tinggi dengan penambahan metanol. Hal ini disebabkan penambahan metanol yang menggeser kesetimbangan reaksi ke arah kanan atau pembentukkan produk sehingga meningkatkan konversi. Dengan semakin meningkatnya konversi akibat meningkatnya laju reaksi dan bergesernya kesetimbangan reaksi, maka densitas biodiesel akan semakin naik karena masih adanya trigliserida yang tidak terkonversi.

Berdasarkan SK Dirjen Migas No. $3674 \mathrm{~K} / 24 / 2006$ tentang spesifikasi BBM jenis biodiesel dengan range $850-890 \mathrm{~kg} / \mathrm{m}^{3}$, hasil analisis density yang diperoleh menunjukkan bahwa sampel biodiesel untuk analisa density telah memenuhi spesifikasi. Hasil diatas menunjukkan bahwa variasi rasio molar metanol/stearin tidak terjadi perubahan yang terlalu signifikan terhadap parameter uji densitas dan masih dalam range yang dapat digunakan sebagai bahan bakar biodiesel.

\subsubsection{Hasil Analisis Viskositas Kinematik Pada $40{ }^{\circ} \mathrm{C}$ \\ Viskositas adalah tahanan yang} dimiliki fluida yang dialirkan dalam pipa kapiler terhadap gaya gravitasi atau dinyatakan sebagai fungsi gesekan dari bahan bakar itu sendiri. Jika viskositas rendah maka besaran tahanan untuk mengalir relatif rendah, sebaliknya jika viskositas tinggi maka tahanan untuk mengalir tinggi. Hasil analisa viskositas menunjukkan hubungan dengan hasil densitas, dimana semakin besar nilai densitas maka semakin tinggi nilai viskositas karena semakin tinggi nilai densitas maka semakin kental minyak biodiesel yang diperoleh.

Uji viskositas kinematik dimaksudkan untuk menguji kekentalan kinematik dari cairan produk minyak yang transparan maupun yang kedap cahaya (gelap), dengan mengukur waktu alir secara gravitasi melalui sebuah viskometer gelas kapiler yang telah dikalibrasi. Viskositas dinamik adalah rasio antara tegangan geser dengan kecepatan geser. Koefsien viskositas dinamik adalah ukuran hambatan cairan untuk mengalir, biasanya disebut viskositas cairan. Dari hasil analisa viskositas pada sampel biodiesel dengan variasi metanol 5, 7, 9 dan 11 tidak terjadi kenaikkan yang signifikan terhadap nilai viskositas. Viskositas biodiesel terendah yang didapat adalah $4.3 \mathrm{cSt}$ dengan variasi rasio molar metanol/stearin 5 sedangkan viskositas tertinggi adalah $5.1 \mathrm{cSt}$ dengan variasi rasio molar metanol/stearin 11 dapat dilihat dari garfik pada gambar 3.2.

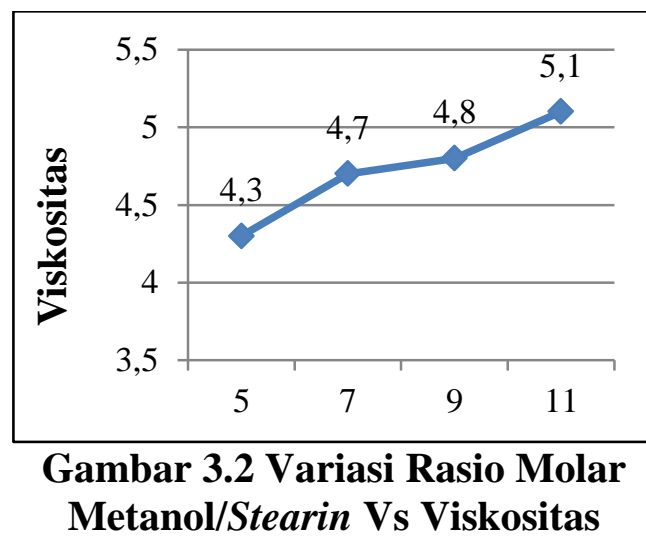

Berdasarkan SK Dirjen Migas No. $3674 \mathrm{~K} / 24 / 2006$ tentang spesifikasi BBM jenis biodiesel, hasil analisis viskositas kinematik yang didapat menunjukkan bahwa sampel biodiesel untuk analisa viskositas kinematik telah memenuhi spesifikasi.

\subsubsection{Hasil Analisis Air dan Sedimen}

Penentuan air dan sedimen dalam bahan bakar biodiesel dimaksudkan untuk menentukan ketepatan volume air bebas dan sedimen. Selain itu air dan sedimen dalam bahan bakar dapat mengakibatkan kerusakan fasilitas penyimpanan pada sistem mesin bahan bakar. Akumulasi sedimen dalam tangki penyimpanan dan penyumbatan aliran minyak dari tangki ke pembakaran.

Air dapat menyebabkan pengkaratan pada tangki dan peralatan. Jika ada deterjen, air dapat membentuk emulsi selain itu keberadaan air juga dapat mempercepat pertumbuhan mikrobiologi pada sistem pembakaran.

Berdasarkan SK Dirjen Migas No. $3674 \mathrm{~K} / 24 / 2006$ tentang spesifikasi BBM jenis diesel hasil analisis air dan sedimen diatas terhadap sampel variasi rasio molar metanol/stearin 5, 7, 9 dan 11 yang memiliki spesifikasi maksimal $0.05 \%$ vol maka sampel yang dianalisa dinyatakan on-spec karena telah 
memenuhi spesifikasi dapat dilihat dari grafik pada gambar 3.3.

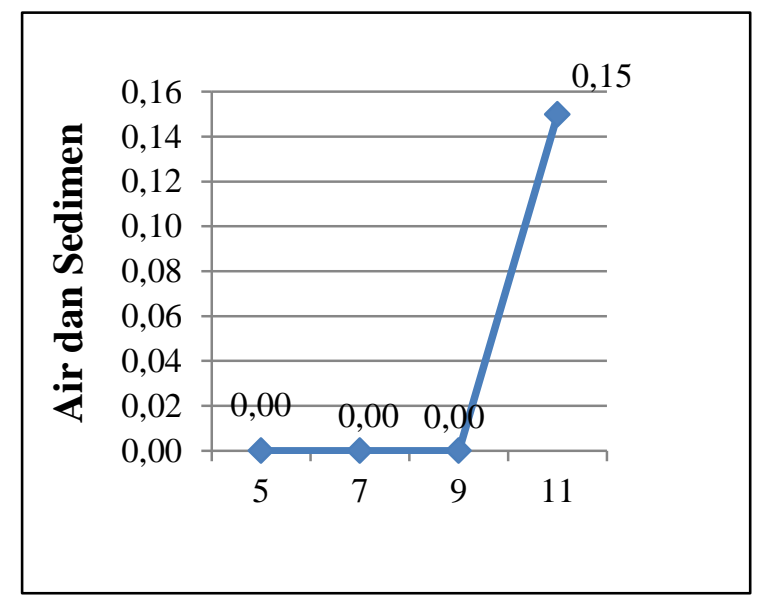

Gambar 3.3. Variasi Rasio Metanol Vs Air dan Sedimen

\subsubsection{Hasil Analisis Temperatur Distilasi 90\%}

Angka temperatur distilasi $90 \%$ menggambarkan sifat volatilitas bahan bakar hidrokarbon. Hal ini digunakan untuk mengindikasikan seberapa besar konsentrasi fatty acid methyl ester yang ada dalam sampel. Fatty acid methyl ester biasanya terdistilasi pada $360{ }^{\circ} \mathrm{C}$. Jika kandungan fatty acid (trigeliserida) terlalu banyak dalam bahan bakar, angka tersebut akan lebih tinggi. Sebaliknya jika angka distilasi yang jauh lebih rendah dari $360{ }^{\circ} \mathrm{C}$ akan menunjukkan bahwa kandungan metanol terlalu banyak dalam bahan bakar.

Produsen biodiesel menggunakan angka ini untuk menentukan apakah reaksi konversi sudah berjalan sempurna atau belum. Angka distilasi yang tinggi menunjukkan bahwa reaksi konversi fatty acid belum sempurna dan angka yang rendah menunjukkan adanya metanol yang terbawa oleh produk biodiesel. Bagi pengguna biodiesel, kandungan fatty acid yang terlalu banyak dalam bahan bakar akan mengakibatkan kesulitan untuk men-start mesin, terlebih pada cuaca dingin. Kandungan metanol yang terlalu tinggi akan berujung pada rusaknya seal-seal mesin. Untuk menentukan angka distilasi tersebut, digunakan Metode
ASTM D-1160 dengan memanaskan sampel sampai temperatur tertentu hingga 90\% sampel teruapkan. Hasil analisis temperatur distilasi $90 \%$ pada sampel variasi rasio molar metanol/stearin 5, 7, 9 dan 11 dapat dilihat dari grafik pada gambar 3.4.

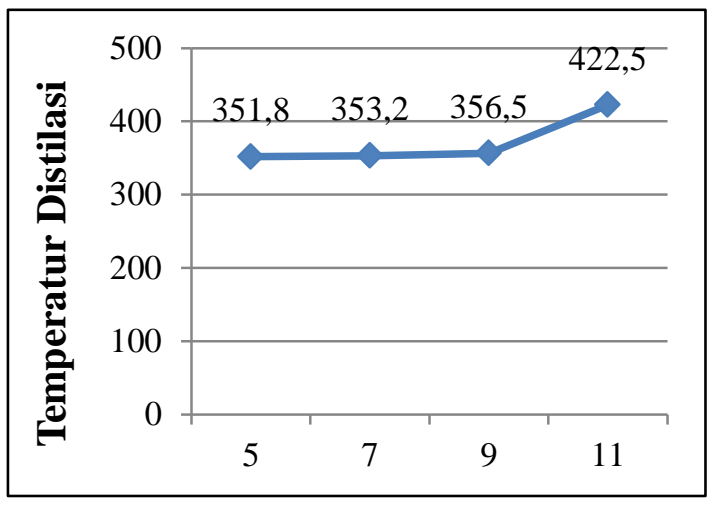

Gambar 3.4 Variasi Rasio Molar Metanol/Stearin Vs Temperatur Distilasi

Berdasarkan SK Dirjen Migas No. 3674K/24/2006 tentang spesifikasi BBM jenis diesel hasil analisis temperatur distilasi $90 \%$ diatas terhadap sampel variasi rasio molar metanol/stearin 5, 7, 9 dan 11 yang memiliki spesifikasi maksimal $360{ }^{\circ} \mathrm{C}$ maka sampel dengan variasi rasio molar metanol/stearin 11 tidak memenuhi spesifikasi dan dinyatakan Off Spec dan untuk variasi rasio molar metanol/stearin 5, 7 dan 9 yang dianalisa dinyatakan On Spec karena telah memenuhi spesifikasi.

\subsubsection{Hasil Analisis Angka Iodium}

Angka Iodium atau angka iodine menunjukkan kestabilan biodiesel terhadap degradasi kualitas yang disebabkan oleh oksidasi. Angka iodium adalah ukuran empirik banyaknya ikatan rangkap (dua) di dalam (asam-asam lemak penyusun) biodiesel dan dinyatakan dalam sentigram iodium yang diabsorpsi per gram contoh biodiesel (\%-b iodium terabsorpsi). Satu mol iodium terabsorpsi setara dengan satu mol ikatan rangkap (dua).

Salah satu parameter penting penentuan kualitas biodiesel dapat ditentukan dengan angka iodium. Angka iodium menjelaskan banyaknya konsumsi iodium yang diperlukan untuk mengoksidasi 
kontaminan yang ada di dalam sampel biodiesel. Angka iodium digunakan untuk menjelaskan jumlah ikatan rangkap pada biodiesel. Semakin tinggi angka iodium menunjukkan semakin tinggi radikal bebas, kontaminasi atau semakin banyaknya ikatan rangkap dalam rantai metil ester biodiesel. Hasil analisa angka iodium dari variasi rasio molar metanol/stearin 5, 7, 9 dan 11 dapat dilihat dari grafik pada gambar 3.5.

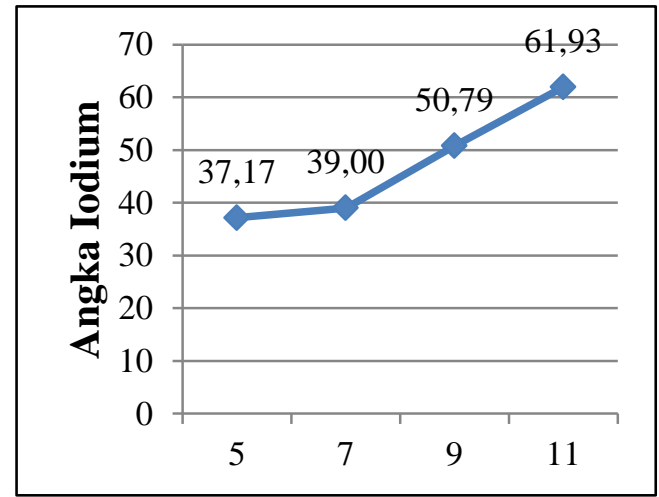

Gambar 3.5 Variasi Rasio Molar Metanol/Stearin vs Angka Iodium

Berdasarkan SK Dirjen Migas No. 3674K/24/2006 tentang spesifikasi BBM jenis biodiesel hasil analisis angka iodium diatas terhadap sampel variasi rasio molar metanol/stearin 5, 7, 9 dan 11 yang memiliki spesifikasi maksimal $115 \%$ massa (g-I2/100 g) maka sampel dengan variasi rasio molar metanol/stearin 5, 7, 9 dan 11 yang dianalisa dinyatakan On Spec karena telah memenuhi spesifikasi.

\subsubsection{Hasil Micro Carbon Residu}

Residu karbon dalam produk perminyakan merupakan bagian sisa setelah suatu percontoh menjalani peruraian dengan pemanasan. Micro Carbon Residu menggunakan ASTM D-4530-03, Standar Test Method for Determination of Carbon Residue (Micro Method). Saat bahan bakar berada pada temperatur tinggi tanpa oksigen, maka dapat terpirolisis menjadi residu karbon.

Semakin tinggi suhu temperatur distilasi $90 \%$ yang didapat maka berbanding lurus dengan hasil residu karbon dimana semakin berat pula residu karbon yang didapat, ini dapat disebabkan oleh kurang sempurnanya dalam pembentukan biodiesel dan dapat juga diakibatkan dari kotoran yang terdapat pada biodiesel diakibatkan dari penyaringan yang tidak baik.

Residu karbon menunjukkan kotoran yang masih terkandung dalam biodiesel, semakin tinggi residu karbon yang didapat maka semakin banyak juga zat pengotor dalam biodiesel. Sebaliknya semakin rendah nilai residu karbon yang didapat maka semakin sedikit zat-zat pengotor dalam biodiesel yang diperoleh, hasil analisa residu karbon dapat dilihat dari grafik pada gambar 3.6.

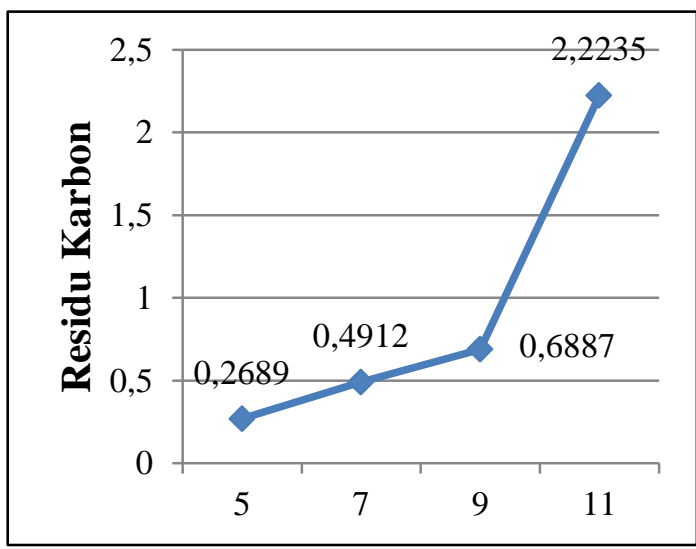

\section{Gambar 3.6 Variasi Rasio Molar Metanol/Stearin vs Residu Karbon}

Untuk variasi rasio molar metanol/stearin 5 dapat dinyatakan On Spec karena telah memenuhi spesifikasi. Dari hasil analisa untuk variasi metanol variasi rasio molar metanol/stearin 7, 9 dan 11 menunjukkan bahwa sampel yang dianalisa off spec karena tidak memenuhi spesifikasi berdasarkan SK Dirjen Migas No. $3674 \mathrm{~K} / 24 / 2006$ tentang spesifikasi BBM jenis biodiesel memiliki batasan residu karbon maks $0,3 \%$ massa.

\section{KESIMPULAN DAN SARAN}

\subsection{Kesimpulan}

Dari pembahasan tersebut, maka kesimpulan dari penelitian ini, yaitu :

1. Transesterifikasi adalah tahap konversi dari stearin menjadi metil ester, melalui reaksi dengan metanol dan menghasilkan produk samping gliserol dengan kondisi operasi temperatur $65-70 \quad{ }^{\circ} \mathrm{C}$. Biodiesel yang 
terbentuk dari variasi penambahan metanol, terdapat kenaikan dari standar mutu biodiesel seperti densitas (854.1 - 857.2 $\left.\mathrm{kg} / \mathrm{m}^{3}\right)$, viskositas $(4,3-5,1 \mathrm{cSt})$, air dan sedimen $(0,00-0,15 \%$ vol $)$, temperatur distilasi $\left(351,8-422,5{ }^{\circ} \mathrm{C}\right)$, angka iodium $(37,17-61,93 \%$ massa) dan residu karbon (0,2- $2,2 \%$ massa).

2. Variasi rasio molar metanol/stearin yang memenuhi sesuai Standar Nasional Indonesia (SNI 04-7182 : 2006) adalah penambahan variasi rasio molar metanol/stearin 5 .

\subsection{Saran}

Saran yang dapat diberikan dari penelitian ini, yaitu diperlukan analisa lebih lanjut untuk mengetahui apakah biodiesel yang dihasilkan sudah sesuai dengan standar mutu biodiesel, diantaranya dengan uji nilai kalor, angka setana, kandungan gliserol bebas, gliserol total dan bilangan saponifikasi serta variasi faktor lain.

\section{DAFTAR PUSTAKA}

American Oil Chemists Society AOCS Cd 125. 2007. Standard Test Methode for Withdrawn (Historical Interest Only) Iodine Value of Fats and Oils. Philadelphia: AOCS International.

American Society for Testing and Materials ASTM D-445. 2007. Standard Test Methode for KinematicViscosity of Petroleum Products. Philadelphia: ASTM International.

American Society for Testing and Materials ASTM D-1160. 2007. Standard Test Methode for Distillation of Petroleum Products at Reduced Pressure. Philadelphia: ASTM International.

American Society for Testing and Materials ASTM D-4007. 2007. Standard Test Methode for Water and Sedimen in Crude Oil by the Centrifuge Method. Philadelphia: ASTM International.
American Society for Testing and Materials D4052-11. 2012. Standard Test Method for Density and Relative Density of Liquids by Digital Density Meter. Philadelphia: ASTM International.

American Society for Testing and Materials ASTM D-4530. 2007. Standard Test Methode for Determination of Carbon Residue. Philadelphia: ASTM International.

Herizal dan Rahman, M.2008. Optimalisasi Transesterifikasi Minyak Kelapa Sawit Menjadi Biodiesel dengan Katalis $\mathrm{NaOH}$. Lembaran Publikasi Lemigas Volume 43 (3), hlm. 61-66

Kussuryani,Y dan Anwar, C. 2009. Bahan Bakar Nabati Biodiesel dan Jaminan Mutu Biodiesel. Lembaran Publikasi Lemigas. 43 (3), hlm. 247-255.

Mulyazmi.2008. Pengambilan Asam Oleat dari Minyak Kelapa. Jurnal Teknos- 2K. 8 (2), hlm.60-66 
P-ISSN: 2089-5925 E-ISSN: 2621-9328

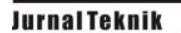

Jurnal Teknik Patra Akademika

Pire

Arademika

Volume 10 No. 01 Juli 2019 